How to Cite

Hepsiba, N., Subhashini, A., Raju, M., \& Rao, Y. P. (2018). Changing role of teachers in the present society. International

Journal of Health \& Medical Sciences, 1(1), 35-38. https://doi.org/10.31295/ijhms.v1n1.37

\title{
Changing Role of Teachers in the Present Society
}

\author{
Netala Hepsiba \\ BENIAH College of Education Burugupudi, E.G Dist. \& Andhra University, Visakhapatnam, India \\ Corresponding author email: hepsibanethala@gmail.com
}

\author{
A. Subhashini \\ Faculty of Education A.U.P.G. Centre, Tadepalligudem, India
}

M.V.R. Raju

Andhra University, Visakhapatnam, India

Y.F.W. Prasada Rao

Andhra University, Visakhapatnam, \& Bharatiar University, Coimbatore, India

\begin{abstract}
The young today are facing a world in which communication and information revolution has led to changes in all spheres: scientific, technological, political, economic, social and cultural. To be able to prepare our young people to face the future with confidence purpose and responsibility, the crucial role of teachers cannot be overemphasized. Given these multidimensional demands, Role of teachers also has to change. In the past, teachers used to be a major source of knowledge, the leader, and educator of their student's school life. The changes that took place in education have initiated to change the role of teachers. In this article, we will examine how the role of teachers in the present society has to change.

Keywords---bureaucrats, emphasis, social mobility, technocrats.
\end{abstract}

\section{Introduction}

Education is a tool to empower the individual; however, how much it can empower depends on the person. The process can begin at the childhood stage itself. When the process of education can be child-centred learning, students are able to see their own role in the transformation. At the same time societal change comes from the collective transformation of the individuals within that society. Education has and did bring about phenomenal changes in every aspect of human life. Francis J. Brown remarks that Education is a process which brings about changes in the behaviour of society. It is a process which enables every individual to effectively participate in the activities of society and to make positive contribution to the progress of society. But the entire paradigm is or the pivot for it is a 'teacher' at all the various stages. So, the responsibility comes on the shoulders of teachers', who are called the 'Builders of a Nation'. As Dr. S. Radhakrishnan said, "The teacher's place in the society is of vital importance. He acts as the pivot for the transmission of intellectual traditions and technical skill from generation to generation and helps to keep the lamp of civilization burning". A more recent reflection is of Dr. Abdul Kalam, a nuclear scientist who rose to be the President of India. He said, "If a country is to be corruption-free and become a nation of beautiful minds, I strongly feel there are three key societal members who can make a difference. They are the father, the mother and the teacher."

ISSN 2632-9433

Received Jan 10, 2018 / Accepted Jun 20, 2018 / Published Jul 05, 2018 


\section{Research Method}

\section{Data Collection Method}

I adopted this method to depict the prevailing status of teacher in the society. I've collected secondary research data which helped me to draw the best outcomes which a teacher can reap from the learner and exhibits the modern role of teachers in the present society.

Table 1

The below table visualizes the changes that occurred in the teacher's role

\begin{tabular}{ll}
\hline From & To \\
\hline Transmitter of knowledge & Guide \& Facilitator of Knowledge \\
Controller of learning & Creator of Learning Environment \\
Always Expert & Collaborator \& Co-learner \\
Expository & Interactive \\
\hline
\end{tabular}

All these changes taking place which results in the creation of new learning environment to facilitate the emergence of responsible knowledge society emphasizing lifelong learning with meaningful and enjoyable learning experiences.

Technology plays a vital role in this modern world. As a result of the innovative technological changes, all the sectors of the economy is being influenced by the scientific growth. The education field is not an exemption to this. Technical background became compulsory to teach the students in present days. Teachers have to use computers, projectors, photocopier etc., to teach the children. They need to be able to use and handle scientific equipment effectively. Instead of teaching chalk face, they need to inspire the students. Hence, the role of teachers also has to change according to the growth in Science and Technology.

\section{Results and Analysis}

\section{Education in the Present Period}

Since the time immemorial teachers, though not all have been doing it in their own way. But the emerging scene is that education today is oriented to promoting values of an urban, competitive consumer society. Through the existing education system, India did produce in the last six decades number of scientists, professionals, and technocrats who have excelled in their fields and made a mark at the national and international levels. The top scientists, doctors, engineers, researchers, professors, etc. not those who were educated abroad but had got their entire education in India. And hence, the system is working. However, it is not a question of the extent to which education provides or fails to provide employment to people but it is a question of education providing modern technology for the benefit of the poor and deprived people encompassing all spheres, social groups and for everyone. There comes the question of the quality of education. Instead of merely viewing the growing population as a liability; which we use to do, we should change the population into an asset and strength; seem to be happening now. We see the Western and European world is very much interested in India and its systems. Education then is means and source of human development. In order to achieve that it seems that we need to see the seeming hindrances in the present system so as to reorient them and gear up the entire system on to the level, it must function. First, let us see the three main deficiencies in the present education system. They may be described as follows:

a) It does not generate or fortify the type of knowledge that is relevant to our changed society.

b) The technology associated with a particular body of knowledge is inappropriate to our stage of development in terms of its employment potential or investment demands.

c) It has failed to provide value framework which may prepare committed politicians, bureaucrats, technocrats, and professionals on whom our nation can depend for a sophisticated system of support services to be useful in taking the country to the highest level.

How can we go about it? Maybe:

a) To make all areas of education to be oriented more scientifically and objectively; 
b) To achieve social equality; mutual tolerance of one and all either religious, linguistic, caste, class, etc. providing equal opportunities for social mobility to all.

\section{Education and Social Change - Role of Teachers}

In describing education as an instrument of social change, three things are important: the agents of change, the content of change, and the social background of those who are seeking to be changed, i.e. students.

Educational institutions under the control of different cultural groups; politically reflect the values of those groups which support and control education.

Looking back at the Indian history all the social reformers, emphasized values like the removal of caste restrictions, equality of women, doing away with social customs and practices which are not based on scientific temper, and so on. They regarded education as a flame or light of knowledge which dispelled the darkness of ignorance.

The use of education for spreading the values of modernization came to be emphasized from the 1960s and 1970s onwards. Education was sought to be utilized as a channel for the spread of modernity.

In a static society, the main function of the educational system is to transmit the cultural heritage to the new generations. But in a changing society, these keep on changing from generation to generation and the educational system in such a society must not only transmit the cultural heritage, but also aid in preparing the young for adjustment to any changes in them that may have occurred or are likely to occur in future. Consequently, in such modern complex societies, education is called upon to perform an additional function of becoming.

Thus, the relationship between the educational system and society is mutual; sometimes the society influences changes in the educational system and at other times the educational system influences changes in the society. As such a 'teacher' is a social reformer and modern thinker. He/she need transform oneself and pass it on to his/her students too.

\section{Modernization of Education in India and the Challenges Involved in it}

The modernization of education in India becomes a special problem in several ways. India has adopted the path of economic development within the framework of a free society and therefore it cannot adopt authoritarian means to modernize education. The center has to get the willing consent of the states and each state has to get the willing consent of its elected representatives in their legislative assemblies before introducing any major change in the allocation of resources to education or in the educational system itself. Secondly, India has no colonies to depend on for resources to meet the expenditure on modernizing its educational system. It has to depend on its own self and find out its own resources which are bound to be very limited. But, it can avail assistance from advanced countries and international agencies like UNESCO which have developed programmes to assist educational development in developing countries. However, the fact that this aid will also be limited has to be taken into account Thirdly, India has lots of diversities. Its economy is mixed, including modern factories along with traditional agriculture. Its tribal, rural and urban groups show very wide contrasts in their physical and social conditions of living. The different levels of development at which the various sections of society stand differentiate their educational needs and complicate the problem of educational development. The aims, methods, and organization of education which may be functional for one group may be dysfunctional for the other. Lastly, in western societies, economic modernization preceded political and social modernization. Consequently, in their educational thinking, they could lay more emphasis on the needs of the individual than on the economic needs of the country. But India, being largely agricultural and poor has to think of the economic needs of the country before it thinks of the needs of individuals. It cannot initially afford to waste its resources on educational programmes that are not productive in economic terms. Thus the Indian education system needs a complete overhaul through proper legislation and its effective implementation. Legislations should be made taking into account the regional diversities of each state. The masses should be made aware of the new developments.

\section{Conclusion}

Education has become one of the influential instruments of social change in India. It has led to the mobilization of people's aspirations for development and change. Thus in modern complex national societies, education can neither be regarded as a controlling force conserving cultural heritage nor could it be viewed as an agent of social change. It can only be regarded as a cooperative force in bringing about social changes decided by the forces possessing more 
pervasive power in society. Thus the Indian education system needs a complete overhaul through proper legislation and its effective implementation. Legislations should be made taking into account the regional diversities of each state. The masses should be made aware of the new developments. In such a crucial shift of educational objectives, a 'teacher' needs to change and teacher education need to be redesigned and need to be functional not philosophical alone.

\section{Acknowledgements}

This research was supported by my colleagues "Y.F.W.PRASADA RAO Sir, M.V.R.RAJU Sir and A.SUBHASHINI Madam." who provided insight and expertise that greatly assisted the research. I would also like to show my gratitude to the institutions and institutional staff who helped to collect the data required for my research. I immensely thankful to all of those who helped me to complete my research.

\section{References}

Ahuja, R. (1992). Social problems in India. Rawat publications.

Ahuja, R. (2003). Society in India: Concepts, Theories and Recent Trends. Rawat Publications.

Astuti, P. S., Wardana, I. K., Puspawati, D. A., \& Sukanadi, N. L. (2018). Interactive lesson study as a competence indicator of prospective English teachers. International Journal of Social Sciences and Humanities (IJSSH), 2(2), $15-25$.

Chávez, S. A. R., \& Quijije, K. K. B. (2018). A Challenge for Teachers of Inclusive Higher Education. International Research Journal of Management, IT and Social Sciences (IRJMIS), 5(2), 129-135.

Cochran-Smith, M., \& Lytle, S. L. (1999). Chapter 8: Relationships of knowledge and practice: Teacher learning in communities. Review of research in education, 24(1), 249-305.

Maba, W. (2017). Teacher's Perception on the Implementation of the Assessment Process in 2013 Curriculum. International Journal of Social Sciences and Humanities (IJSSH), 1(2), 1-9.

Maba, W., \& Mantra, I. B. N. (2017). An Analysis of Assessment Models Employed by The Indonesian Elementary School Teachers. International Journal of Social Sciences and Humanities (IJSSH), 1(1), 39-45.

Macías, E. I. P., Cedeño, H. A. C., \& Chávez, G. M. R. (2018). Importance of Improving Resilience in TeachingLearning Process of Students with Disabilities. International Research Journal of Management, IT and Social Sciences (IRJMIS), 5(2), 120-128.

Ruan, X. (2018). Engagement and negotiation: Exploring a tertiary female EFL teacher's professional agency in her career development in PR China. International Journal of Linguistics, Literature and Culture (IJLLC), 4(3), 4663.

Suiraoka, I. P., Duarsa, D. P. P., Wirawan, I. D. N., \& Bakta, I. M. (2017). Perception of Parents, Teachers, and Nutritionist on Childhood Obesity and Barriers to Healthy Behavior: A Phenomenological Study. International Journal of Health Sciences (IJHS), 1(2), 1-11. 